\title{
Synergistic Effect of Silver Nanoparticles with Neomycin or Gentamicin Antibiotics on Mastitis-Causing Staphylococcus aureus
}

\author{
Shahab Jamaran, Bahareh Rahimian Zarif* \\ Department of Biology, Sanandaj Branch, Islamic Azad University, Sanandaj, Iran \\ Email: "Bahareh_r_z@yahoo.com
}

Received 10 May 2016; accepted 18 June 2016; published 21 June 2016

Copyright (C) 2016 by authors and Scientific Research Publishing Inc.

This work is licensed under the Creative Commons Attribution International License (CC BY).

http://creativecommons.org/licenses/by/4.0/

(c) (i) Open Access

\begin{abstract}
Objective: Mastitis is one of the most costly diseases in dairy cows, which greatly decreases milk production. Use of antibiotics in cattle leads to antibiotic-resistance of mastitis-causing bacteria. The present study aimed to investigate synergistic effect of silver nanoparticles (AgNPs) with neomycin or gentamicin antibiotic on mastitis-causing Staphylococcus aureus. Materials and Methods: In this study, 46 samples of milk were taken from the cows with clinical and subclinical mastitis during the august-October 2015 sampling period. In addition to biochemical tests, nuc gene amplification by PCR was used to identify strains of Staphylococcus aureus. Disk diffusion test and microdilution were performed to determine minimum inhibitory concentration (MIC) and minimum bactericidal concentration (MBC). Fractional Inhibitory Concentration (FIC) index was calculated to determine the interaction between a combination of AgNPs and each one of the antibiotics. Results: Twenty strains of Staphylococcus aureus were isolated from 46 milk samples and were confirmed by PCR. Based on disk diffusion test, $35 \%, 10 \%$ and $55 \%$ of the strains were respectively susceptible, moderately susceptible and resistant to gentamicin. In addition, $35 \%, 15 \%$ and $50 \%$ of the strains were respectively susceptible, moderately susceptible and resistant to neomycin. According to FIC index, gentamicin antibiotic and AgNPs had synergistic effects in $\mathbf{5 0 \%}$ of the strains. Furthermore, neomycin antibiotic and AgNPs had synergistic effects in $45 \%$ of the strains. Conclusion: It could be concluded that a combination of AgNPs with either gentamicin or neomycin showed synergistic antibacterial properties in Staphylococcus aureus isolates from mastitis. In addition, some hypotheses were proposed to explain antimicrobial mechanism of the combination.
\end{abstract}

\section{Keywords}

Staphylococcus aureus, Mastitis, Silver Nanoparticles, Gentamicin, Neomycin, Synergistic

\footnotetext{
${ }^{*}$ Corresponding author.
}

How to cite this paper: Jamaran, S. and Zarif, B.R. (2016) Synergistic Effect of Silver Nanoparticles with Neomycin or Gentamicin Antibiotics on Mastitis-Causing Staphylococcus aureus. Open Journal of Ecology, 6, 452-459. 


\section{Introduction}

Mastitis is caused by a range of pathogenic microorganisms but mammary infections caused by Staphylococcus aureus are considerably important, which greatly affect global livestock industry due to decrease in milk production and quality, cost of treatment, etc. [1]. Various studies have shown that $S$. aureus is a pathogenic microorganism causing subclinical and clinical mastitis in buffalo species [2]. Staphylococcus genus belongs to Micrococcus family. These bacteria are gram-positive, non-motile, non-spore-forming rods and facultative anaerobes. Members of this genus have more than 20 species spread in different habitats. Some of them inhabit in the skin, skin glands and mucous membranes of animals. Thereby, these microorganisms are transferred to animal products such as cheese, milk, meat and peripheral resources such as soil, sand and dust, air and natural water [3].

Mastitis is treated by antibiotic. Thus, antibiotic resistance is increasing among mastitis-causing strains [4] [5]. From non-economic perspective, antibiotic resistance and its transmission to humans can be cited. From economic perspective, reduced milk production, eliminated replacement costs, reproductive problems, discarded milk, increased labor and predisposed animals to other diseases can be noted. Therefore, scientists have looked for compounds that can be used instead of antibiotics or be used in combination with antibiotics [6] [7].

Nanotechnology refers to the study and construction of nanometer-scale materials in 1 - 100 nanometers. These nanoscale materials have unique and new physical, chemical and biological properties in comparison with larger particles [8] [9]. Silver nanoparticles (AgNPs) are the most widely used nanoparticles next to carbon nanotubes with numerous applications in medicine [10]. Several studies have been conducted for identification of antimicrobial effects of AgNPs [11]-[13]. Nano silver technology refers to suspension form of colloidal silver ions in an aqueous solution. AgNPs have unique physical and chemical properties, which enhance antimicrobial activity. Antimicrobial uses of AgNPs were greatly considered with regard to emergence of antibiotic-resistant bacteria [14] [15]. The most important mechanism of AgNPs is manifested through attacking respiratory chain of different microorganisms, which affect other cellular processes that ultimately leads to cell death [16]. Increased activity of antibiotics in combination with silver was investigated in some studies [17]-[19]. On the other hand, it is confirmed that low concentration of AgNPs has low toxicity to humans. Therefore, it is recommended to simultaneously use AgNPs and common antibiotics. However, further studies are needed to realize the efficiency of this method. The present study aimed to investigate synergistic effect of AgNPs with either neomycin or gentamicin antibiotics on mastitis-causing S. aureus.

\section{Materials and Method}

\subsection{Sampling}

Milk samples were taken from the cows with clinical and subclinical mastitis in sterile conditions in industrial, semi-industrial and traditional cattle farms in Sanandaj during the august-October 2015 sampling period. The cows with clinical mastitis were detected through observation and palpation of the breast, clots in milk and mammary gland inflammation. California mastitis test (CMT) was also performed for detection of subclinical mastitis (one positive and above one positive) [20]. The breast teats were sterilized with 70\% ethyl alcohol to collect milk samples. Some milk was discarded. Then, $10 \mathrm{ml}$ of milk was milked into a sterilized tube. The samples were kept at $-20^{\circ} \mathrm{C}$ until the time of the tests.

\subsection{Isolation and Identification of Bacteria}

Milk samples were removed from the freezer to be melted. Then, $0.01 \mathrm{ml}$ of each sample was cultured on Mannitol salt agar that contains: Peptone (10 g/L), Mannitol (10 g/L), Sodium chloride (75 g/L), Phenol red (0.025 $\mathrm{g} / \mathrm{L})$ and Agar ( $15 \mathrm{~g} / \mathrm{L})$. The cultures were incubated at $37^{\circ} \mathrm{C}$ for 24 hours. Finally, yellow colonies were initially identified as $S$. aureus by Gram staining as well as catalase, DNase and coagulase tests [21].

\subsection{Molecular Identification of Strains}

The kit manufactured by Cinnagen Company (Karaj-Iran) was used for extraction of DNA of strains cultured in BHI. The nuc gene was amplified by polymerase chain reaction for molecular identification of S. aureus strains. 
The primers used for amplification of nuc gene were F (5'-GCGATTGATGGTGATACGGTT-3') and R (5'-AGCCAAGCCTTGACGAACTAAAGC-3') based on previous studies. The product size was 279 bp [22]. PCR reactions were performed in a final volume of $25 \mathrm{ml}$ containing $12.5 \mu \mathrm{l}$ master mix (with $2 \mathrm{x}$ concentration), $1 \mu \mathrm{l}$ of each primer, $2 \mu \mathrm{l}$ of extracted DNA and $8.5 \mathrm{ml}$ of double distilled water. Distilled water and the DNA extracted from Staphylococcus aureus PTCC 1112 standard strains were used instead of DNA sample respectively in positive and negative control. PCR reaction was performed in thermocycler manufactured by Senso Quest Company (Germany). Following conditions were setup: initial denaturation ( 5 minutes at $\left.95^{\circ} \mathrm{C}\right), 35$ cycles of denaturation $\left(1 \mathrm{~min}\right.$ at $\left.94^{\circ} \mathrm{C}\right)$, annealing $\left(30\right.$ seconds at $\left.55^{\circ} \mathrm{C}\right)$, elongation $\left(1.5 \mathrm{~min}\right.$ at $\left.72^{\circ} \mathrm{C}\right)$ and final elongation (at $72^{\circ} \mathrm{C}$ and 3.5 minutes). PCR product was electrophoresed in $1.5 \%$ agarose gel.

\subsection{Disc Diffusion}

Disc diffusion method was used to evaluate antibacterial activity of neomycin and gentamicin antibiotics alone and in combination with AgNPs. According to CLSI Standard, selective concentration of neomycin was $10 \mathrm{UI}$ while selective concentration of gentamicin was $10 \mu \mathrm{g}$ [23]. Selective concentration of AgNPs was $10 \mu \mathrm{g}$. Bacterial suspension was prepared as follows: a colony was grown in nutrient broth overnight. Turbidity was matched with McFarland Standard 0.5. Then, the colony was cultured on Mueller Hinton agar medium and 6 mm disks impregnated with standard concentrations of antibiotics and AgNPs were placed on the culture medium. The disks impregnated with standard concentrations of antibiotics were used for combined disks in which $10 \mu \mathrm{g}$ of AgNPs were added. Finally, the plates were incubated at $37^{\circ} \mathrm{C}$ for 24 hours. Growth inhibitory zone was measured by subtracting diameter of the disc from diameter of growth inhibitory zone. Experiments are done in triplicate.

\subsection{MIC and MBC Determination}

For this purpose, the microdilution method with 96-well microplates was used with slight modifications. Minimum inhibitory concentration (MIC) refers to the lowest concentration of the combination that inhibits growth of microorganisms. In this study, MIC and MBC were calculated for neomycin and gentamicin antibiotics alone and in combination with AgNPs.

The bacterial inoculated was a fresh cultured in nutrient broth. Turbidity was matched with McFarland Standard 0.5. Different concentrations of AgNPs and antibiotics were prepared in following ranges: 5 - $50 \mu \mathrm{g} / \mathrm{ml}$ (5, 10, 15, 20, 30, 40 and 50). The 96-well plates were prepared through distribution of $95 \mu \mathrm{l}$ of Mueller-Hinton broth media and $5 \mu \mathrm{l}$ of bacterial inoculated in each well. Furthermore, $100 \mu \mathrm{l}$ of each prepared solution was poured into the wells to examine MIC of AgNPs or antibiotics. Moreover, $50 \mu \mathrm{l}$ AgNPs and $50 \mu \mathrm{l}$ antibiotics were poured into the wells to examine MIC of AgNPs and antibiotics in combination. Different concentrations of ampicillin standard antibiotic were used as positive control. The microplates were incubated for $24 \mathrm{~h}$ at $37^{\circ} \mathrm{C}$. Growth rate was determined by absorption at a wavelength of $600 \mathrm{~nm}$ using microplate reader (stat fax 2100, United States) [24]. Contents of each well $(200 \mathrm{ml})$ were transferred to an Eppendorf tube (Eppendorf, Hamburg, Germany) with $2 \mathrm{ml}$ of BHI medium to examine MBC. The tube was incubated at $37^{\circ} \mathrm{C}$ for 12 hours. Finally, 20 $\mathrm{ml}$ of the Eppendorf with no turbidity was inoculated in BHI agar and incubated at $37^{\circ} \mathrm{C}$ for 24 hours. $\mathrm{MBC}$ refers to the lowest concentration with $100 \%$ reduction in CFU/ml compared to a positive control (without using antimicrobial agent) [24].

The synergy between anti-bacterial drugs is usually expressed by sum of Fractional Inhibitory Concentration (FIC) of the two combinations. FIC is calculated by the following formula for combination A:

$$
\text { FIC }=\frac{\text { MIC of antibacterial A in combination }}{\text { MIC of antibacterial A alone }}
$$

FIC was also calculated for combination B with the same formula. Thus:

$$
\sum \text { FIC=FIC of antibacterial A+FIC of antibacterial B }
$$

$\sum$ FIC index was used to identify nature of the interaction between the two antibacterial combinations. The interaction was either synergism, antagonism, additive or indifferent. The index is interpreted as follows: $1 \geq$ synergistic; 1 = additive; 1.1 - 2.0 = indifferent (non-interactive); $0.2 \leq$ antagonistic [25] [26]. 


\section{Results}

In this study, 46 milk samples were collected from infected cattle. After inoculation and biochemical tests, 24 strains were detected as $S$. aureus. Finally, molecular identification was performed by nuc gene amplification where 20 strains were confirmed as $S$. aureus. Studied primers properly amplified 279bp segment of nuc gene. Gel electrophoresis relevant to seven strains is shown in Figure 1.

In all samples, growth inhibition zone around disc of combination of AgNPs with either gentamicin or neomycin antibiotics was larger than the zone around the discs impregnated with antibiotics alone (Figure 2). Mean diameters of growth inhibition zone in 20 strains of $S$. aureus isolates are shown in Diagram 1.

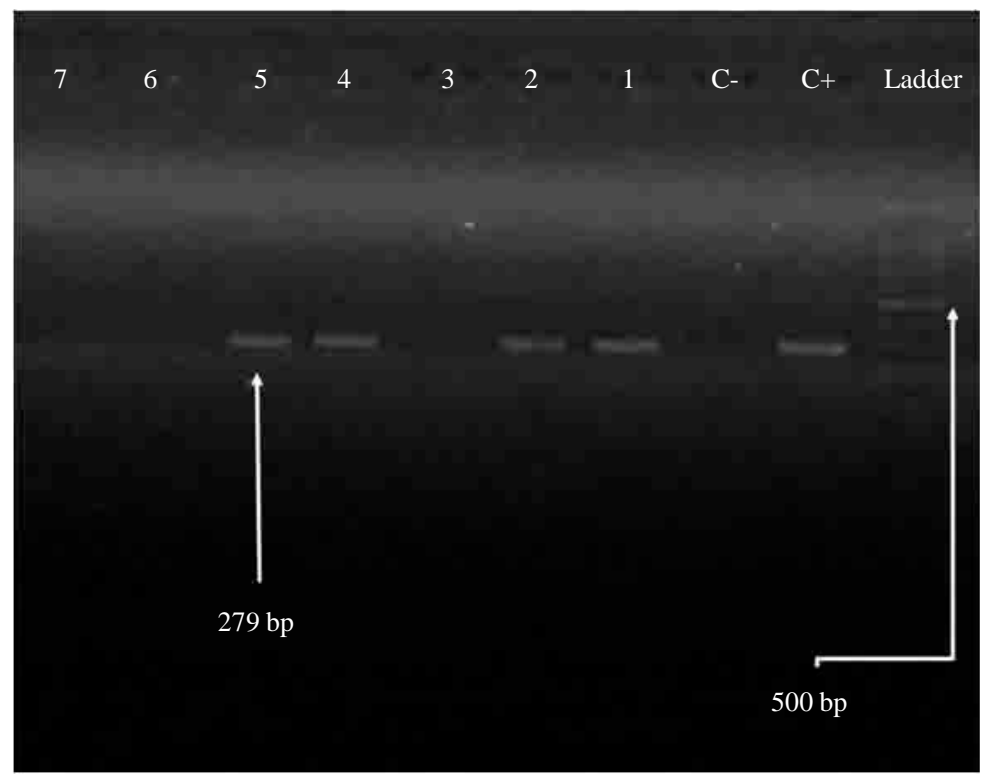

Figure 1. Gel electrophoresis. Wells 1, 2, 4 and 5: strains confirmed by nuc gene amplification, Wells 3, 6 and 7: unconfirmed strains

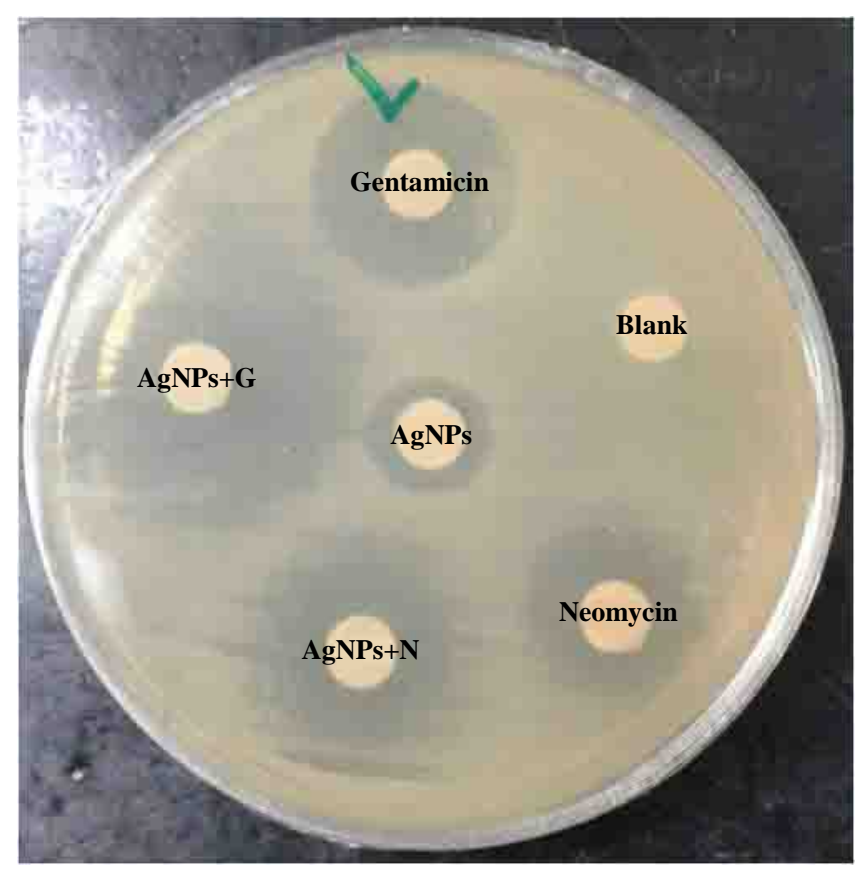

Figure 2. Growth inhibition zone around the discs. 


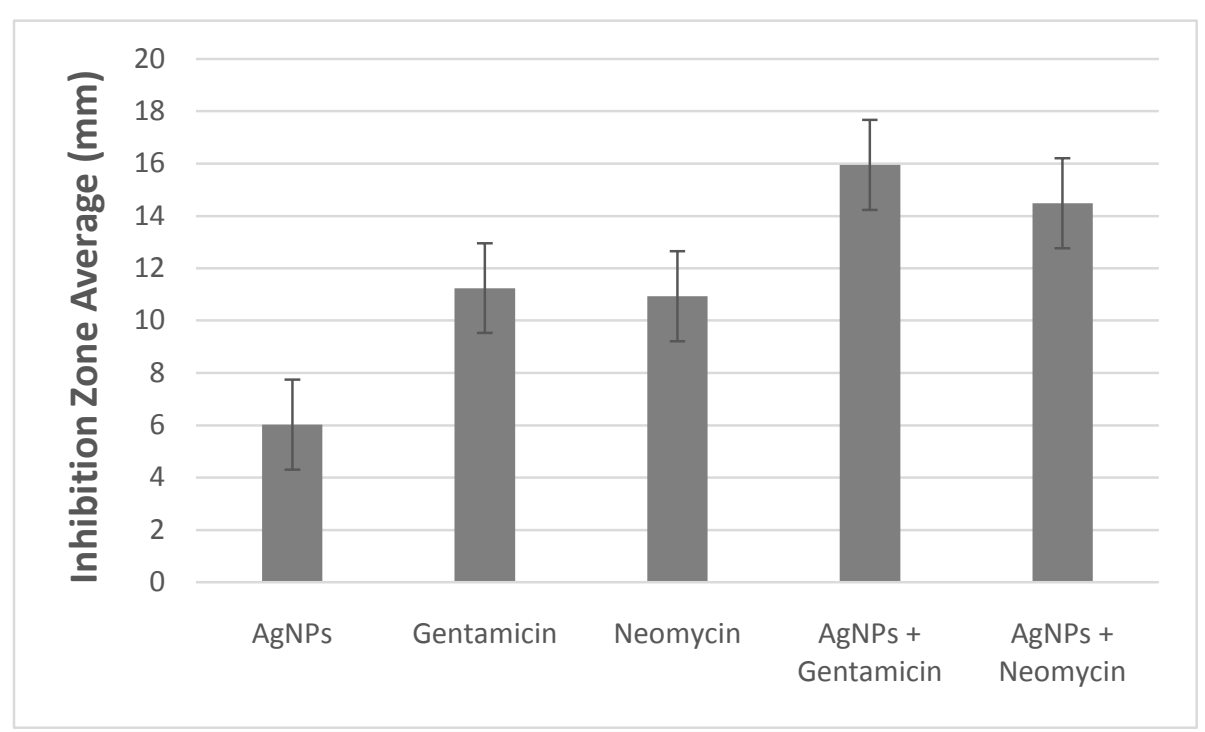

Diagram 1. Mean diameter of growth inhibition zone of 20 Staphylococcus aureus isolates.

In Diagram 2, mean of MIC and MBC is given by the type of antimicrobial material. According to the diagram, MIC and MBC of AgNPs in combination with any of the antibiotics increased antibacterial effect of the antibiotics. In addition, mean of MIC and MBC of the combinations were lower than each antibiotic alone. In this diagram, mean of MIC and MBC are given for studied 20 strains. The results of the FIC may vary in each strain. Totally, averages represent synergistic effect of the combinations.

\section{FIC Index}

Table 1 shows FIC index for determining the type of interaction between antimicrobial agents for each strain. The results showed synergistic effect of gentamicin antibiotic and AgNPs in 50\% of strains as well as synergistic effect of AgNPs and neomycin antibiotic in $45 \%$ of strains. The rate of synergistic effect was acceptable; therefore, a combination of these drugs can be used to treat the disease.

\section{Discussion}

Among 46 samples taken from cattle, 38 cattle had clinical mastitis and 8 cattle had subclinical mastitis based on California mastitis test. In this study, 24 strains were identified as $S$. aureus by biochemical tests among which 20 strains were confirmed by PCR. As cited earlier, biochemical tests alone are not enough for identification of bacteria. Therefore, it is essential to use molecular tests. In total, 20 (43.47\%) S. aureus strains were isolated from 46 milk samples, which showed high prevalence of mastitis-causing S. aureus in cattle population in Sanandaj. Among the 20 strains, 18 strains were isolated from the cattle with clinical mastitis and 2 strains were isolated from the cattle with subclinical mastitis.

According to CLSI standardized disk diffusion testing, 35\%, 10\% and 55\% of the strains were respectively susceptible, intermediate and resistant to gentamicin and 35\%, 15\% and 50\% of the strains were respectively susceptible, intermediate and resistant to neomycin. Therefore, prevalence of resistance isolates to antibiotics is high. Growth inhibition zone of combination of antibiotics with AgNPs was compared with CLSI standards. The results showed that the resistance to gentamicin and neomycin was respectively reduced to $15 \%$ and $45 \%$. Thus, it can be concluded that combination of gentamicin and AgNPs was more effective than neomycin and AgNPs based on disk diffusion tests.

According to FIC index, gentamicin and AgNPs had synergistic effects in 50\% of the strains. In addition, neomycin and AgNPs had synergistic effects in $45 \%$ of the strains. The only antagonistic effect was observed in strain 20. The interaction in the rest of the strains was mostly indifferent and additive in some cases. High rate of synergistic interactions and low rate of antagonistic interactions suggested use of combination of these drugs for treatment of mastitis caused by S. aureus. 


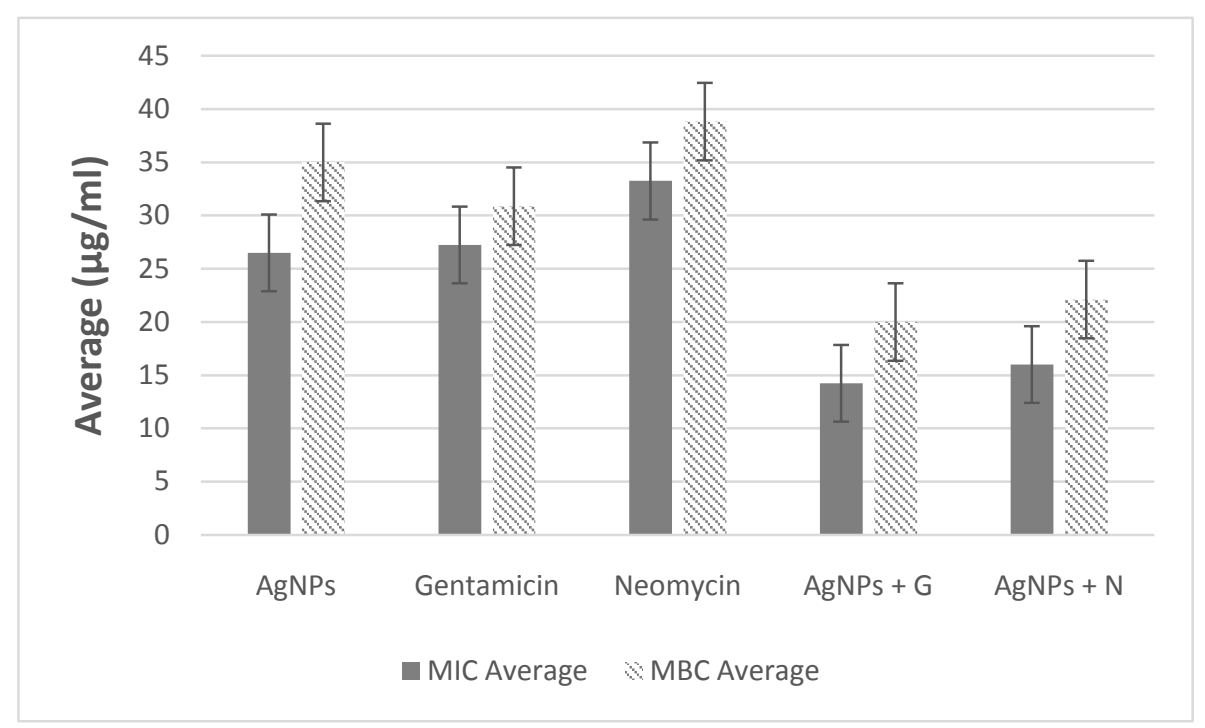

Diagram 2. Mean of MIC and MBC by type of antimicrobial regent.

Table 1. FIC index to determine the interaction between antimicrobial agents.

\begin{tabular}{ccccc}
\hline Strain No. & AgNPs + gentamycin & Interaction & AgNPs + neomycin & Interaction \\
\hline $\mathbf{1}$ & 1 & Additive & 1.25 & Indifferent \\
$\mathbf{2}$ & 0.416 & Synergistic & 1.5 & Indifferent \\
$\mathbf{3}$ & 0.333 & Synergistic & 0.666 & Synergistic \\
$\mathbf{4}$ & 1.166 & Indifferent & 0.416 & Synergistic \\
$\mathbf{5}$ & 1.8 & Indifferent & 1.8 & Indifferent \\
$\mathbf{6}$ & 0.666 & Synergistic & 1.166 & Indifferent \\
$\mathbf{7}$ & 1.33 & Indifferent & Indifferent \\
$\mathbf{8}$ & 1.5 & Indifferent & Synergistic \\
$\mathbf{9}$ & 0.291 & Synergistic & 0.416 & Synergistic \\
$\mathbf{1 0}$ & 1 & Additive & 1.166 & Indifferent \\
$\mathbf{1 1}$ & 0.5 & Synergistic & 0.583 & Synergistic \\
$\mathbf{1 2}$ & 2.33 & Indifferent & Additive \\
$\mathbf{1 3}$ & 0.66 & Synergistic & Synergistic \\
$\mathbf{1 4}$ & 1.166 & Indifferent & 0.833 & Synergistic \\
$\mathbf{1 5}$ & 0.416 & Synergistic & 0.375 & Additive \\
$\mathbf{1 6}$ & 0.5 & Synergistic & 1 & Indifferent \\
$\mathbf{1 7}$ & 0.625 & Synergistic & 1.166 & Synergistic \\
$\mathbf{1 8}$ & 0.833 & Synergistic & 0.75 & Synergistic \\
$\mathbf{1 9}$ & 1.6 & Indifferent & Indifferent \\
$\mathbf{2 0}$ & 2.13 & Antagonistic & 2.66 & Antagonistic \\
\hline
\end{tabular}

So far, scientists have identified mechanism of action of neomycin and gentamicin antibiotics [27]. Several mechanisms have been proposed for AgNPs. Some theories suggest that these particles disrupt cellular respiration chain by reacting with oxygen. In addition, reaction of AgNPs with bacterial cellular membrane leads to cell death [28]. Some studies have shown that antibacterial effect of AgNPs is manifested through inhibition of unwinding of DNA [29]. Mechanism of the interaction between gentamicin and neomycin antibiotics and AgNPs can be explained as follows: 
1) As cited earlier, AgNPs, gentamicin and neomycin can kill bacteria through different mechanisms. If the bacteria are resistant to one of the antibiotics, another antimicrobial agent can kill bacteria through a completely different mechanism. This type of combination of drugs is frequently used especially when the bacteria become resistant.

2) Active hydroxyl and amide groups are found in gentamicin and neomycin. These groups easily react with and bind to AgNPs. We know whenever an antimicrobial agent more enters the bacterial cell its effect is highlighted. The synergistic effect may be due to drug delivery of AgNPs to the cell. It is well-known that hydrophobic groups are found in cellular membranes. Gentamicin and neomycin are hydrophilic but AgNPs are hydrophobic. Thereby, AgNPs unlike antibiotics can easily pass cellular membrane. It can be concluded that silver-nanoparticle-bound antibiotics can be easily delivered to the cell.

3) Batarseh showed that silver inhibits unwinding of DNA [29]. When AgNPs reacts with DNA, nanoparticles-bound antimicrobial molecules inhibit unwinding of DNA due to spatial restrictions, which leads to more serious damage to the cell.

\section{Conclusion}

The results of this study showed antibacterial synergistic effect of combination of AgNPs and gentamicin or neomycin in S. aureus isolates from mastitis. Some hypotheses were offered to explain antimicrobial mechanism of these combinations. Further studies are needed to highlight efficiency of AgNPs against other bacteria and other antibiotics. In addition, detailed empirical evidence is needed to clarify mechanism of this synergistic effect.

\section{Acknowledgements}

This is a part of Shahab Jamaran's M.Sc. thesis. The authors wish to extend their gratitude to Sanandaj Branch of Islamic Azad University for its support.

\section{References}

[1] Ahmady, M. and Kazemi, S. (2013) Detection of the Enterotoxigenic Genes (sei, sej) in Staphylococcus aureus Isolates from Bovine Mastitis Milk in the West Azerbaijan of Iran. Comparative Clinical Pathology, 22, 649-654. http://dx.doi.org/10.1007/s00580-012-1460-3

[2] Ali, M., Ahmad, M., Muhammad, K. and Anjum, A. (2011) Prevalence of Sub Clinical Mastitis in Dairy Buffaloes of Punjab, Pakistan. Okara, 150, 42.

[3] Hennekinne, J.-A., De Buyser, M.-L. and Dragacci, S. (2012) Staphylococcus aureus and Its Food Poisoning Toxins: Characterization and Outbreak Investigation. FEMS Microbiology Reviews, 36, 815-836. http://dx.doi.org/10.1111/j.1574-6976.2011.00311.x

[4] Park, Y.K., Fox, L.K., Hancock, D.D., McMahan, W. and Park, Y.H. (2012) Prevalence and Antibiotic Resistance of Mastitis Pathogens Isolated from Dairy Herds Transitioning to Organic Management. Journal of Veterinary Science, 13, 103-105. http://dx.doi.org/10.4142/jvs.2012.13.1.103

[5] Szweda, P., Schielmann, M., Frankowska, A., Kot, B. and Zalewska, M. (2014) Antibiotic Resistance in Staphylococcus aureus Strains Isolated from Cows with Mastitis in Eastern Poland and Analysis of Susceptibility of Resistant Strains to Alternative Nonantibiotic Agents: lysostaphin, Nisin and Polymyxin B. Journal of Veterinary Medical Science, 76, 355-362. http://dx.doi.org/10.1292/jvms.13-0177

[6] Hagnestam-Nielsen, C. and Østergaard, S. (2009) Economic Impact of Clinical Mastitis in a Dairy Herd Assessed by Stochastic Simulation Using Different Methods to Model Yield Losses. Animal, 3, 315-328. http://dx.doi.org/10.1017/S1751731108003352

[7] Nielsen, C., Østergaard, S., Emanuelson, U., Andersson, H., Berglund, B. and Strandberg, E. (2010) Economic Consequences of Mastitis and Withdrawal of Milk with High Somatic Cell Count in Swedish Dairy Herds. Animal, 4, 1758-1770. http://dx.doi.org/10.1017/S1751731110000704

[8] Cascio, C., Geiss, O., Franchini, F., Ojea-Jimenez, I., Rossi, F., Gilliland, D., et al. (2015) Detection, Quantification and Derivation of Number Size Distribution of Silver Nanoparticles in Antimicrobial Consumer Products. Journal of Analytical Atomic Spectrometry, 30, 1255-1265. http://dx.doi.org/10.1039/C4JA00410H

[9] Roy, R., Pal, A. and Chaudhuri, A.N. (2015) Antimicrobial Effect of Silver Nanoparticle on Pathogenic Organisms Isolated from East Kolkata Wetland. IJAR, 1, 745-752.

[10] Takenaka, S., Karg, E., Roth, C., Schulz, H., Ziesenis, A., Heinzmann, U., et al. (2001) Pulmonary and Systemic Dis- 
tribution of Inhaled Ultrafine Silver Particles in Rats. Environmental Health Perspectives, 109, 547. http://dx.doi.org/10.1289/ehp.01109s4547

[11] Hussain, S.M., Javorina, A.K., Schrand, A.M., Duhart, H.M., Ali, S.F. and Schlager, J.J. (2006) The Interaction of Manganese Nanoparticles with PC-12 Cells Induces Dopamine Depletion. Toxicological Sciences, 92, 456-463. http://dx.doi.org/10.1093/toxsci/kfl020

[12] Sarkar, S., Jana, A.D., Samanta, S.K. and Mostafa, G. (2007) Facile Synthesis of Silver Nano Particles with Highly Efficient Anti-Microbial Property. Polyhedron, 26, 4419-4426. http://dx.doi.org/10.1016/j.poly.2007.05.056

[13] Sondi, I. and Salopek-Sondi, B. (2004) Silver Nanoparticles as Antimicrobial Agent: A Case Study on E. coli as a Model for Gram-Negative Bacteria. Journal of Colloid and Interface Science, 275, 177-182. http://dx.doi.org/10.1016/j.jcis.2004.02.012

[14] Guzman, M., Dille, J. and Godet, S. (2012) Synthesis and Antibacterial Activity of Silver Nanoparticles against GramPositive and Gram-Negative Bacteria. Nanomedicine: Nanotechnology, Biology and Medicine, 8, 37-45. http://dx.doi.org/10.1016/j.nano.2011.05.007

[15] Radzig, M., Nadtochenko, V., Koksharova, O., Kiwi, J., Lipasova, V. and Khmel, I. (2013) Antibacterial Effects of Silver Nanoparticles on Gram-Negative Bacteria: Influence on the Growth and Biofilms Formation, Mechanisms of Action. Colloids and Surfaces B: Biointerfaces, 102, 300-306. http://dx.doi.org/10.1016/j.colsurfb.2012.07.039

[16] Prabhu, S. and Poulose, E.K. (2012) Silver Nanoparticles: Mechanism of Antimicrobial Action, Synthesis, Medical Applications, and Toxicity Effects. International Nano Letters, 2, 1-10. http://dx.doi.org/10.1186/2228-5326-2-32

[17] Habash, M.B., Park, A.J., Vis, E.C., Harris, R.J. and Khursigara, C.M. (2014) Synergy of Silver Nanoparticles and Aztreonam against Pseudomonas aeruginosa PAO1 Biofilms. Antimicrobial Agents and Chemotherapy, 58, 5818-5830. http://dx.doi.org/10.1128/AAC.03170-14

[18] Morones-Ramirez, J.R., Winkler, J.A., Spina, C.S. and Collins, J.J. (2013) Silver Enhances Antibiotic Activity against Gram-Negative Bacteria. Science Translational Medicine, 5, 1-21. http://dx.doi.org/10.1126/scitranslmed.3006276

[19] Shahverdi, A.R., Fakhimi, A., Shahverdi, H.R. and Minaian, S. (2013) Synthesis and Effect of Silver Nanoparticles on the Antibacterial Activity of Different Antibiotics against Staphylococcus Aureus and Escherichia Coli. Nanomedicine: Nanotechnology, Biology and Medicine, 3, 168-171. http://dx.doi.org/10.1016/j.nano.2007.02.001

[20] Fosgate, G.T., Petzer, I.-M. and Karzis, J. (2013) Sensitivity and Specificity of a Hand-Held Milk Electrical Conductivity Meter Compared to the California Mastitis Test for Mastitis in Dairy Cattle. The Veterinary Journal, 196, 98-102. http://dx.doi.org/10.1016/j.tvjl.2012.07.026

[21] Kateete, D.P., Kimani, C.N., Katabazi, F.A., Okeng, A., Okee, M.S., Nanteza, A., et al. (2010) Identification of Staphylococcus Aureus: DNase and Mannitol Salt Agar Improve the Efficiency of the Tube Coagulase Test. Annals of Clinical Microbiology and Antimicrobials, 9, 1-23. http://dx.doi.org/10.1186/1476-0711-9-23

[22] Merlino, J., Watson, J., Rose, B., Beard-Pegler, M., Gottlieb, T., Bradbury, R., et al. (2002) Detection and Expression of Methicillin/Oxacillin Resistance in Multidrug-Resistant and Non-Multidrug-Resistant Staphylococcus aureus in Central Sydney, Australia. The Journal of Antimicrobial Chemotherapy, 49, 793-801. http://dx.doi.org/10.1093/jac/dkf021

[23] Watts, J.L. and Clinical and Laboratory Standards Institute (2008) Performance Standards for Antimicrobial Disk and Dilution Susceptibility Tests for Bacteria Isolated from Animals: Approved Standard. National Committee for Clinical Laboratory Standards.

[24] Paredes, D., Ortiz, C. and Torres, R. (2014) Synthesis, Characterization, and Evaluation of Antibacterial Effect of Ag nanoparticles against Escherichia Coli O157: H7 and Methicillin-Resistant Staphylococcus aureus (MRSA). International Journal of Nanomedicine, 9, 1717-1729.

[25] Habiba, K., Bracho-Rincon, D.P., Gonzalez-Feliciano, J.A., Villalobos-Santos, J.C., Makarov, V.I., Ortiz, D., et al. (2015) Synergistic Antibacterial Activity of PEGylated Silver-Graphene Quantum Dots Nanocomposites. Applied Materials Today, 1, 80-87. http://dx.doi.org/10.1016/j.apmt.2015.10.001

[26] Te Dorsthorst, D., Verweij, P., Meis, J., Punt, N. and Mouton, J. (2002) Comparison of Fractional Inhibitory Concentration Index with Response Surface Modeling for Characterization of in Vitro Interaction of Antifungals against Itraconazole-Susceptible and-Resistant Aspergillus fumigatus Isolates. Antimicrobial Agents and Chemotherapy, 46, 702707. http://dx.doi.org/10.1128/AAC.46.3.702-707.2002

[27] Greenwood, D. (2007) Antimicrobial Chemotherapy. Oxford University Press, Oxford.

[28] Rai, M., Yadav, A. and Gade, A. (2009) Silver Nanoparticles as a New Generation of Antimicrobials. Biotechnology Advances, 27, 76-83. http://dx.doi.org/10.1016/j.biotechadv.2008.09.002

[29] Batarseh, K.I. (2004) Anomaly and Correlation of Killing in the Therapeutic Properties of Silver (I) Chelation with Glutamic and Tartaric Acids. Journal of Antimicrobial Chemotherapy, 54, 546-548. http://dx.doi.org/10.1093/jac/dkh349 


\section{Submit or recommend next manuscript to SCIRP and we will provide best service for you:}

Accepting pre-submission inquiries through Email, Facebook, Linkedin, Twitter, etc A wide selection of journals (inclusive of 9 subjects, more than 200 journals)

Providing a 24-hour high-quality service

User-friendly online submission system

Fair and swift peer-review system

Efficient typesetting and proofreading procedure

Display of the result of downloads and visits, as well as the number of cited articles

Maximum dissemination of your research work

Submit your manuscript at: http://papersubmission.scirp.org/ 